\title{
Assessment of energy return on energy investment (EROEI) of oil bearing crops for renewable fuel production
}

\author{
A. Restuccia, S. Failla, D. Longo, L. Caruso, I. Mallia, G. Schillaci \\ DiGeSA, Mechanics and Mechanization Section, University of Catania, Italy
}

\begin{abstract}
As reported in literature the production of biodiesel should lead to a lower energy consumption than those obtainable with its use. So, to justify its consumption, a sustainable and "low input" production should be carried out. In order to assess the sustainability of Linum usitatissimum, Camelina sativa and Brassica carinata cultivation for biodiesel production in terms of energy used compared to that obtained, the index EROEI (Energy Return On Energy Invested) has been used. At this aim, an experimental field was realised in the south-eastern Sicilian land. During the autumn-winter crop cycle, no irrigation was carried out and some suitable agricultural practices have been carried out taking into account the peculiarity of each type of used seeds. The total energy consumed for the cultivation of oil bearing crops from sowing to the production of biodiesel represents the Input of the process. In particular, this concerned the energy embodied in machinery and tools utilized, in seed, chemical fertilizer and herbicide but also the energy embodied in diesel fuels and lubricant oils. In addition, the energy consumption relating to machines and reagents required for the processes of extraction and transesterification of the vegetable oil into biodiesel have been calculated for
\end{abstract}

Correspondence: Giampaolo Schillaci DiGeSA, Mechanics and Mechanization Section, University of Catania, Via S. Sofia,100, 95123 Catania, Italy

E-mail: giampaolo.schillaci@unict.it

Keywords: Biodiesel, EROEI, net energy balance, oil bearing crops, renewable energy.

Contributions: Restuccia A., data collected, data analyzing, manuscript writing and references search; Failla S., data analyzing, manuscript writing and references search; Longo D., Caruso L. data collected and references search; Mallia I., data collected, data analyzing and reference search; Schillaci G., reviewing.

Conflict of interests: the authors declare no potential conflict of interests.

Funding: the work was supported by the project AGROSO (Evaluation of high erucic acid oilseed species in the Mediterranean environment for use in the energy sector as an alternative to mineral oil with a high environmental impact) funded by MiPAAF (Ministry of Agriculture, Food and Forestry).

(C) Copyright A. Restuccia et al., 2013

Licensee PAGEPress, Italy

Journal of Agricultural Engineering 2013; XLIV(s2):e107

doi:10.4081/jae.2013.s2.e107

This article is distributed under the terms of the Creative Commons Attribution Noncommercial License (by-nc 3.0) which permits any noncom- each crops. The energy obtainable from biodiesel production, taking into account the energy used for seed pressing and for vegetable oil transesterification into biodiesel, represents the Output of the process. The ratio Output/Input gets the EROEI index which in the case of Camelina sativa and Linum usatissimum is greater than one. These results show that the cultivation of these crops for biofuels production is convenient in terms of energy return on energy investment. The EROEI index for Brassica carinata is lower than one. This could means that some factors, concerning mechanisation and climatic conditions, were not suitable to ensure higher crop yields.

\section{Introduction}

In Europe, agriculture plays an important role in providing renewable energy resources. The quote of renewable energy deriving from this sector grew, in recent years, from $3.6 \%$ in 2005 to $10.5 \%$ in 2010. According to the GSE, in 2012, renewable resources production from agriculture brought in nearly 12,250 GWh (GSE, 2012; Ortenzi, 2013).

To achieve the main objectives set under the NES (National Energy Strategy), which was launched on 8 March 2013, it will need to take into consideration some strategic parameters including that relating to the energetic valorisation of biomass for the production of biofuels. It is also to highlight that the bio-energy production must create jobs as well as important opportunities for safeguarding the land and the national landscapes, especially in marginal lands (Monni, 2013).

In this context, to support the development of agro-energy in , it could be of great importance to focus on crops adapted to marginal land and non-irrigated or historically used for other crops and now being abandoned.

The cultivars of linseed (Linum usitatissimum L.) have been widely used in in the past years, recording a yield per hectare almost double the national average (Crescini, 1969: Rivoira, 2001).

The cultivars of Brassica carinata has attracted considerable interest also in , thanks to greater vigor, productive potential and increased resistance to biotic and abiotic stress shown by this species in some environments in respect of other varieties (eg. Brassica juncea and Brassica napus) (Mazzoncini et al., 1993; Progetto Fi.Sic.A., 2008; Lazzeri et al., 2009).

In addition, Camelina sativa together with other oilseed crops, have garnered interest as potential sources of biodiesel. C. sativa has attracted interest as an oil crop because of its ability to grow in various climatic conditions, low nutrient requirements and resistance to disease and pests (Zubr, 1996; Gugel and Falk, 2006; Francis and Warwick, 2009).

In summary, the choice of these high value species erucic, cultivated for energy purposes, derived from their ability to adapt to soil and climatic unfavourable conditions, enhancing thus the marginal areas or abandoned areas of agricultural land.

To be considered sustainable, the production of biodiesel (cultiva- 
tion, extraction and trans- esterification) should involve lower energy consumption than those obtainable with its use. From energy audits conducted on rapeseed and sunflower it shows that to the phases of agricultural production and transesterification are attributed, in almost equal parts, about $76 \%$ of the total energy used and approximately 15 $\mathrm{MJ} / \mathrm{kg}$ of biodiesel produced. Considering a calorific value of biodiesel equal to $37.3 \mathrm{MJ} / \mathrm{kg}$, approximately 2.5 units of energy (biodiesel) per unit of energy consumed were obtained (Riva et al. 2008).

To assess, from point of view of energetic use, the economic advantages deriving from the cultivation of these crops in order to produce biodiesel, the index EROEI (Energy Return On Energy Invested) has been used. This energetic balance allows to correlate the amount of energy obtained from the crop (Output) with the amount of energy used for its cultivation (Input) as reported in literature (Cosentino et al., 2008; Verani et al., 2008; Lazzeri et al., 2009; D’Avino et al., 2010; Murphy et al., 2010; Unakitan et al., 2010; Pracha and Volk, 2011).

To obtain Input and Output data, energetic equivalents were be used, by choosing those reported in literature and most used (Baldini et al., 1982; Volpi, 1992; Unakitan et al. 2010; Fore et al., 2011).

Most recent energetic equivalents are reported in the literature and are worthy of note, but the values are often aggregated or missing and therefore it was not appropriate to consider them in this work (Singh et al. 2006; Ozkan et al. 2007; Da Silva et al. 2010; Zelina et al. 2011).

At last, this work is preliminary to a subsequent assessment of emissions of greenhouse gases (GHG), calculated taking into account the data input and output of the cultivation/production. This is to meet the sustainability criteria laid down for the supply chain of biofuels established with the RED (Directive 2009/28/EC).

\section{Materials and methods}

\section{The experimental field}

The experimental field was carried out in the province of Siracusa in south-eastern Sicily ( $36^{\circ} 49^{\prime} 02.61$ "N $15^{\circ} 05$ '33 .81" E); it covers an area of about with a maximum width of about and length of about. For this experiment, three non-irrigated plots were realised, one for each species concerned; each plot covers an area of and has a size ofof $80 \mathrm{~m}$ $\times 62 \mathrm{~m}$. To avoid contamination between different species sown and to facilitate the mechanization of cultural practices, a buffer zones of between the plots and the edge of the area, and between the parcels have been left. The field is flat, rectangular in shape, oriented NW-SE and has an altitude of above sea level. The soil is compact, with lightweight skeleton presence and weaving of medium consistency.

\section{The cultural practices and the machines}

Due to the small size of oilseed crops, the tillage were carried out by performing a through preparation of the seed bed. At the beginning of December, a preliminary shredding of existing weed was carried out. The tillage was performed with a shredder having knives on a horizontal rotor, driven by the power take-off, of a width of $2.70 \mathrm{~m}$ and mass of $1,130 \mathrm{~kg}$.

Subsequently, to break the compact layer of the surface soil and aerate it a harrowing was carried out. The farm machine used is a cultivator having 9 chisel plow shovels arranged in two rows, of a width of 2.25 $\mathrm{m}$ and mass of $500 \mathrm{~kg}$. For the refinement of clods created in the previous tillage a hoeing was conducted. This tillage was carried out with a rotary tiller of a width of $2.05 \mathrm{~m}$ and mass of $450 \mathrm{~kg}$.

Sowing and fertilization took place simultaneously in the third decade of December, by distributing $320 \mathrm{~kg} / \mathrm{ha}$ of complex mineral fertilizer (NP 25-15) and $39 \mathrm{~kg} / \mathrm{ha}$ of linseed, $4.2 \mathrm{~kg} / \mathrm{ha}$ of seed C. sativa and $5.3 \mathrm{~kg} / \mathrm{ha}$ of seed $B$. carinata.
For shredding, harrowing, hoeing, the farm machines were connected to a 4 WD tractor of $74 \mathrm{~kW}$ and mass of $3,500 \mathrm{~kg}$.

The seeder used for linseed is universal type with mechanical distribution, 19 distributors and mass of $740 \mathrm{~kg}$, double hopper for seed and fertilizer. The width is $2.50 \mathrm{~m}$ with adjustable spacing between the distributors (the minimum is $13 \mathrm{~cm}$ ). In order to obtain a distance between the rows equal to $26 \mathrm{~cm}$ the distributors were used alternatively, by closing 9 of them. Because of the small size of the seed, the seed depth was maintained between 0.5 and $1 \mathrm{~cm}$. The seeder was connected to a $4 \mathrm{WD}$ tractor of $74.5 \mathrm{~kW}$ and mass of $3,500 \mathrm{~kg}$.

The seeder used for seeds of $C$. sativa and $B$. carinata is precision type with pneumatic distribution. It has three binate rows of distributors with a distance of $7 \mathrm{~cm}$ between rows and $40 \mathrm{~cm}$ between the binate rows, so as to obtain a working width of the machine equal to $1.60 \mathrm{~m}$. In particular, the distance between rows was equal to $2.6 \mathrm{~cm}$ and the depth of sowing $1.5 \mathrm{~cm}$ for $B$. carinata, while the distance between rows was equal to $1.4 \mathrm{~cm}$ and the depth of sowing $0.5 \mathrm{~cm}$ for C. sativa because of the very small size of the seed. The distance between the binate rows was equal to $40 \mathrm{~cm}$ in both cases. The seeder was connected to a $2 \mathrm{WD}$ tractor of $44 \mathrm{~kW}$.

After sowing, the rolling to make homogeneous the surface of the soil and a pre-emergence herbicide treatment were carried out. Doses of $1 \mathrm{~L} /$ ha of product with active ingredient "Linurom" in concentrations of $45 \mathrm{~g} / \mathrm{L}$, for linseed, and doses of $1 \mathrm{~L} / \mathrm{ha}$ of product with active ingredient "Metazachlor" pure in concentrations of $43.5 \mathrm{~g} / \mathrm{L}$ for the remaining crops were used. The volumes distributed were respectively 350 L/ha for linseed and $175 \mathrm{~L} /$ ha for other crops; these volumes correspond to the minimum recommended doses.

The rolling was performed with smooth roller having a width of $2.4 \mathrm{~m}$ and mass of $1000 \mathrm{~kg}$, connected to a 4WD of $78 \mathrm{~kW}$ and mass of $2,540 \mathrm{~kg}$.

The pre-emergence weed control was carried out by a bar sprayer 10 $\mathrm{m}$ wide and flat spray tips. The pressure during the treatment was 20 bar. The sprayer was connected to a $4 \mathrm{WD}$ tractor of $52 \mathrm{~kW}$ and mass of $3,200 \mathrm{~kg}$.

During the growing season of the crop, periodic inspections of the experimental field were carried out which did not reveal the need to conduct additional cultural practices.

The harvesting of the experimental field was carried out in the first ten days of June, upon the completion of the seeds maturation, which was tested by sampling in the experimental field.

A combine harvester was used for the harvesting, commonly used for herbaceous crops, of $167 \mathrm{~kW}$, mass of 10,400 kg and cutter bar of $5 \mathrm{~m}$, by properly adjusting the speed of the awner and the opening of the threshing drum. In detail, given the small size of the seeds and not excessive resistance to detachment from the capsule by the same, the speed of rotation of the awner was set relatively low, amounting to about $850 \mathrm{rpm}$ for $L$. usitatissimum and $650 \mathrm{rpm}$ for $C$. sativa and $B$. carinata. The opening of the threshing drum was set of $6 \mathrm{~mm}$ anteriorly and $2 \mathrm{~mm}$ posteriorly for L. usitatissimum and $12 \mathrm{~mm}$ anteriorly and $3 \mathrm{~mm}$ posteriorly for $C$. sativa and $B$. carinata.

Subsequently, through appropriate laboratory tests were evaluated: the moisture content of the seeds, the thousand seeds weight mass of 1000 seeds and the number of seeds per capsule.

\section{The methodology}

In order to assess the sustainability of Brassica carinata, Camelina sativa, Linum usitatissimum cultivation for biodiesel production in terms of energy used (Input) compared to that obtained (Output), the index EROEI (Energy Return On Energy Invested) has been used.

The Output represents the energy which is possible to obtain by the products used for the cultivation, the Input refers to the factors of production used for the cultivation, whether direct or indirect (machinery 
and equipments, diesel fuel and lubricant oil, products for plant protection, fertilizers, etc.).

This methodology involves the use of the so-called energetic equivalents (or indexes), which represent, in the case of Input, the cost of energy incurred for the use of machinery during the various cultural practices and for the consumption of materials necessary for cultivation (seeds, fertilizers, herbicides, etc.), while, in the case of Output, the energy which can be obtained from the crop (vegetable oil, biodiesel, etc..).

For each farm machine used during the experimentation it was possible to find in the literature the energetic equivalent amount (expressed in $\mathrm{MJ} / \mathrm{h}$ ), which indicates the energy used per each hour of machine use; while the consumption of diesel fuel and lubricant oil are calculated separately (Baldini et al., 1982; Unakitan et al. 2010). Energetic indexes were found in the literature also for seeds, fertilizers, herbicides, diesel fuel and lubricant oil, oil extraction and transesterification; these are expressed in MJ per unit of product (Baldini $e t$ al., 1982; Volpi, 1992; Fore et al., 2011).

To this end, in order to calculate the effective working capacities [ha/h] and then the time units of utilization [h/ha], the effective width of the work [m] and the forward speed [m/s] on the field for each cultural practice were recorded by adopting a standardized methodology.

The diesel fuel consumption was calculated through a direct measurement by using the "top-up" method on the field; furthermore they were verified through the sizing of power, necessary and sufficient, of the tractors used in the different cultural practices.

The consumption of lubricant oil was calculated by taking into account a specific consumption equal to $0,009 \mathrm{~kg} / \mathrm{kWh}$ (Bodria et al., 2006) and an engine load resulting from the ratio between the ideal power calculated through the sizing and the effective available power of the tractors used in the field.

In the case under consideration, the Output is represented by the energy content of biodiesel produced by the transesterification of vegetable oil mechanically extracted from seeds. The energetic equivalent for the biodiesel is considered equal to the calorific power that is $37.25 \mathrm{MJ} / \mathrm{L}$ (Avella et al., 2009).

It is assumed that both for the extraction of oil from seed and for the transesterification of the same are required 5.31 MJ/L of biodiesel (Fore et al., 2011), defined as energy consumed during the processes for machines (screw-press and transesterification machine), electricity, methanol and sodium hydroxide (reagents and catalysts). At the end, these Input data related to the process shall be in addition to those relating to the cultivation in order to obtain the total Input.

\section{Results}

\section{Mechanization and agronomic viewpoint}

The experimental trials has shown different results for the three species cultivated both for mechanization aspect and for agronomic aspects.

The cultural practices were carried out choosing carefully the machines both for their adaptability to the soil structure and to obtain a good final soil tillage in order to facilitate the crops in the first stages of growth. Moreover, accurate adjustments were carried out on the farm machines both in the farm workshop and in the open field, with particular attention to the seeder and to the harvester in order to optimize their efficiency and to reduce losses.

The three crops were grown in the same experimental field respectively in three similar plots for their physical-chemical features. The pre-sowing and post-sowing cultural practices were carried out at the same time for the three crops, so they gave back the same work capacity [ha/h] and unitary time [h/ha]. At the opposite, the sowing has recorded different values more or less remarkable both for the different wide of the seeders and for the different speed with the same seeder (Table 1). In fact, the mechanical seeder have a width double than the precision seeder. In addition, in order to ensure accurate seeding, the forward speeds were kept lower than those normally used in open fields which are greater to $2 \mathrm{~m} / \mathrm{s}$ with these seeders. For this reason also the working capacity were lower (about $1 \mathrm{ha} / \mathrm{h}$ ) and unitary times higher of the average values found in field for the sowing. So, the percentage on the total of the cultural practices is quite high and equal to about $20 \%$ for $C$. sativa and B. carinata while $10 \%$ for $L$. usitatissimum.

As a result, the shredding is the practice that recorded the higher incidence on the total in respect to the other practices. It was around $40 \%$ for all the crops. The others tillage (harrowing and hoeing) showed similar percentage among 12 and $18 \%$ and together account for about $30 \%$. Rolling, weeding and harvesting affect less than $8 \%$, especially the weeding thank to the highest work capacity (about $3.3 \mathrm{ha} / \mathrm{h}$ ).

The total unitary time is rather high for all three crops considered in respect to other crops, quite similar for the $C$. sativa and $B$. carinata

Table 1. Working capacity in the experimental field.

\begin{tabular}{|c|c|c|c|c|c|c|c|}
\hline Cultural practices & $\begin{array}{l}\text { Ve } \\
\mathrm{m} / \mathrm{s}\end{array}$ & $\begin{array}{l}\text { Le } \\
\mathrm{m}\end{array}$ & $\begin{array}{c}\mathrm{Ce} \\
\mathrm{ha} / \mathrm{h}\end{array}$ & $\begin{array}{c}\text { Unitary time } \\
\text { h/ha }\end{array}$ & $\begin{array}{c}\text { Incidence } \\
\text { L. usitatissimum }\end{array}$ & C. sativa & B. carinata \\
\hline Shredding & 0.35 & 2.50 & 0.32 & 3.17 & $42 \%$ & $38 \%$ & $38 \%$ \\
\hline Harrowing & 1.40 & 2.05 & 1.03 & 0.97 & $13 \%$ & $12 \%$ & $12 \%$ \\
\hline Hoeing & 1.10 & 1.90 & 0.75 & 1.33 & $18 \%$ & $16 \%$ & $16 \%$ \\
\hline $\begin{array}{l}\text { Sowing and Fertiliz. } \\
\text { - L. usitatissimum } \\
\text { - C. sativa } \\
\text { - B. carinata }\end{array}$ & $\begin{array}{l}1.55 \\
1.56 \\
1.29 \\
\end{array}$ & $\begin{array}{l}2.35 \\
1.15 \\
1.30 \\
\end{array}$ & $\begin{array}{l}1.31 \\
0.65 \\
0.60\end{array}$ & $\begin{array}{l}0.76 \\
1.55 \\
1.66 \\
\end{array}$ & $10 \%$ & $19 \%$ & $20 \%$ \\
\hline Rolling & 2.20 & 2.20 & 1.74 & 0.57 & $8 \%$ & $7 \%$ & $7 \%$ \\
\hline Weeding & 0.95 & 9.70 & 3.32 & 0.30 & $4 \%$ & $4 \%$ & $4 \%$ \\
\hline \multirow[t]{2}{*}{ Harvesting } & 1.40 & 5.00 & 2.52 & 0.40 & $5 \%$ & $5 \%$ & $5 \%$ \\
\hline & & TOTAL & $\begin{array}{l}\text { L. usitatissimum } \\
\text { C. sativa } \\
\text { B. carinata }\end{array}$ & $\begin{array}{l}7.51 \\
8.29 \\
8.40 \\
\end{array}$ & $100 \%$ & $100 \%$ & $100 \%$ \\
\hline
\end{tabular}


(8.3-8.4 h/ha) and a little lower for the $L$. usitatissimum (7.5 h/ha) due to a greater work capacity of the sowing.

For each crop, in addition to the yield, the thousand seed weight, the relative humidity and the number of seed for capsule have been evaluated (Table 2).

As a result, the agronomic parameters obtained are comparable with those found in literature, except for the $B$. carinata yield. In this last case, the delayed sowing period for this crop has probably led to a reduction in yield which can still oscillate between 0.1 and 1.2 tha (Monti and Venturi, 2007).

The yield of $L$. usitatissimum was very similar $(1.45 \mathrm{t} / \mathrm{ha})$ to that reported in literature that is of about $1.52 \mathrm{t} / \mathrm{ha}$ (Rivoira, 2001). Even the weight of a thousand seeds is one of the values listed in the bibliography: the thousand seeds weight could be in a range between 3 and $15 \mathrm{~g}$ (Crescini, 1969) and for most of commonly variety cultivated between 5 and $10 \mathrm{~g}$ (Rivoira, 2001).

In the case of $C$. sativa, the yield was about $1.1 \mathrm{t} / \mathrm{ha}$ and the thousand seeds weight was about $1.15 \mathrm{~g}$ as reported in other studies where yield was between 1.1 and $3.3 \mathrm{t} / \mathrm{ha}$ and thousand seeds weight of about $1.2 \mathrm{~g}$ (Crescini, 1969; Zubr, 1996; Gugel et al., 2006).

Regarding $B$. carinata, a recent study performed in Sicily reports a yield of about 1.5 tha, that is more than that harvested with the experimental trials and thousand seeds weight of about $3.3 \mathrm{~g}$ that is little less than value reported in Table 1 for this crop (Progetto Fi.Sic.A., 2008).

\section{Energetic viewpoint}

In order to evaluate the sustainability of the energetic crops the
EROEI index was calculated. To do this, the energy gained with the biodiesel producible and that consumed for machines and products used were compared.

In Table 3 is reported the energy consumption for the use of the machine due to the energy embodied in each of them.

The cultural practice that recorded the maximum Energy required was the shredding with an incidence between 34.5 and $38.1 \%$ on the total. This result is strictly related to the high unitary time required by the tillage.

Likewise, the sowing was again the practice that recorded the maximum difference among the three crops due to the different seeders used. In fact, for L. usitatissimum cultivation a value of about the half than the others two crops was registered. Moreover, only one point percentage of difference between $C$. sativa and $B$. carinata was recorded.

On the other hand, the chemical weeding showed the lower energy consumption a little bit more than $1 \%$, also because of the lowest values of energetic equivalents considered in this cultural practice for the tractor and the operating machine.

The total for each crop shows negligible differences between the species and amounts to a few tens of $\mathrm{MJ} / \mathrm{ha}$, due only to the different unitary times of the sowing.

The detailed consumptions of fuel and lubricant are reported in Table 4, where also the percentage of every single practice for each culture is showed.

As already seen for the use of the machines in Table 3, even in this case the differences among the fuel and lubricant consumptions are strictly related to the unitary time needed to carry out each cultural

Table 2. Agronomic parameters.

\begin{tabular}{lcccc} 
Crop & Yield & Thousand seeds weight & Relative humidity & Seeds per capsule \\
& tha & $\mathrm{g} / 1000$ seeds & $\%$ & $\mathrm{n}$ \\
L. usitatissimum & 1,45 & 4,93 & $8,33 \%$ & 9 \\
\hline C. sativa & 1,10 & 1,15 & $6,26 \%$ & 11 \\
B. carinata & 0,85 & 3,12 & $11,74 \%$ & 15 \\
\hline
\end{tabular}

Table 3. Energy consumption due to use of machines.

\begin{tabular}{|c|c|c|c|c|c|c|c|c|c|}
\hline \multirow{2}{*}{$\begin{array}{l}\text { Cultural } \\
\text { practices }\end{array}$} & \multirow[t]{2}{*}{ Unitary time } & \multicolumn{2}{|c|}{ Energetic index } & \multicolumn{2}{|c|}{ Energy required } & \multirow{2}{*}{$\begin{array}{l}\text { Total } \\
\text { MJ/ha }\end{array}$} & \multicolumn{3}{|c|}{ Incidence } \\
\hline & & $\begin{array}{l}\text { tractor } \\
\mathrm{MJ} / \mathrm{h}\end{array}$ & $\begin{array}{l}\text { operating } \\
\text { machine } \\
\mathrm{MJ} / \mathrm{h}\end{array}$ & $\begin{array}{l}\text { tractor } \\
\text { MJ/ha }\end{array}$ & $\begin{array}{c}\text { operating } \\
\text { machine } \\
\text { MJ/ha }\end{array}$ & & L. usitatissimum & $\begin{array}{c}\text { C. sativa } \\
\%\end{array}$ & B. carinata \\
\hline Shredding & 3.17 & $27.13^{[1]}$ & $2.26^{[1]}$ & 86.13 & 7.17 & 93.30 & $38.1 \%$ & $34.9 \%$ & $34.5 \%$ \\
\hline Harrowing & 0.97 & $27.13^{[1]}$ & $6.07^{[1]}$ & 26.26 & 5.87 & 32.13 & $13.1 \%$ & $12.0 \%$ & $11.9 \%$ \\
\hline Hoeing & 1.33 & $27.13^{[1]}$ & $2.51^{[1]}$ & 36.06 & 3.34 & 39.39 & $16.1 \%$ & $14.7 \%$ & $14.6 \%$ \\
\hline $\begin{array}{l}\text { Sowing and fertilizing } \\
\text { - L. usitatissimum } \\
\text { - C. sativa } \\
\text { - B. carinata }\end{array}$ & $\begin{array}{l}0.76 \\
1.55 \\
1.66 \\
\end{array}$ & $\begin{array}{l}27.13^{[1]} \\
27.13^{[1]} \\
27.13^{[1]} \\
\end{array}$ & $\begin{array}{l}1.76^{[1]} \\
1.76^{[1]} \\
1.76^{[1]}\end{array}$ & $\begin{array}{l}20.69 \\
42.01 \\
44.94 \\
\end{array}$ & $\begin{array}{l}1.34 \\
2.73 \\
2.92 \\
\end{array}$ & $\begin{array}{l}22.03 \\
44.73 \\
47.85 \\
\end{array}$ & $\begin{array}{c}9.0 \% \\
- \\
- \\
\end{array}$ & $\begin{array}{c}- \\
16.7 \% \\
-\end{array}$ & $\begin{array}{c}- \\
- \\
17.7 \% \\
\end{array}$ \\
\hline Rolling & 0.57 & $27.13^{[1]}$ & $6.07^{[1]}$ & 15.57 & 3.48 & 19.05 & $7.8 \%$ & $7.1 \%$ & $7.0 \%$ \\
\hline Weeding & 0.30 & $13.08^{[1]}$ & $0.61^{[1]}$ & 3.94 & 0.18 & 4.13 & $1.7 \%$ & $1.5 \%$ & $1.5 \%$ \\
\hline Harvesting & 0.40 & $87.63^{[2]}$ & - & 34.77 & - & 34.77 & $14.2 \%$ & $13.0 \%$ & $12.8 \%$ \\
\hline & & & & TOTAL & $\begin{array}{l}\text { L. usitatissimum } \\
\text { C. sativa } \\
\text { B. carinata }\end{array}$ & $\begin{array}{l}244.81 \\
267.52 \\
270.64 \\
\end{array}$ & $100 \%$ & $100 \%$ & $100 \%$ \\
\hline
\end{tabular}

[1] Baldini et al., 1982; [2] Unakitan et al., 2010. 
practice. In fact, in all cases, the tillage and harvesting recorded in total more than $80 \%$ of the consumption, while the rolling and the chemical weeding were always equal or less than $2 \%$. Also the sowing confirmed a big difference when different seeder was used (about 10\%) and again a small difference when the same seeder was used in two different species (about 1\%).

This result primarily affects the total amount of diesel fuel consumed in three crops. In particular, the cultivation of $L$. usitatissimum involves a saving of about 7-8 kg/ha compared to the other two crops considered.

To assess the total energy consumption for all the products used, fertilizer, herbicide and seeds were considered together to diesel fuel and oil lubricant (Table 5).

Looking at the Table, it appears that the fertilizer represents the product which involves the higher Energy required with value around 7 thousand $\mathrm{MJ} / \mathrm{ha}$ (about $60 \%$ on the total). Also the values of Energy required for the diesel fuel consumption are quite high and around to
3.400 to $3.800 \mathrm{MJ} / \mathrm{ha}$. This two products represent together about $90 \%$ of the total of Energy required for the use of the products during the cultivations.

In the case of $L$. usitatissimum the use of seeds is energetically relevant because of the high quantity used for sowing ( $39 \mathrm{~kg} / \mathrm{ha})$. The seed represents about $8 \%$ of the total Energy required, while for the other two species it remains around to $1 \%$.

An analysis of the energy consumption relating to machinery, diesel fuel, lubricant oil, fertilizer, herbicide and seed showed that the sowing together to the fertilizing becomes the cultural practice which requires more than $65 \%$ of total energy used for the cultivation (Figure 1). The alignment of values concerning the sowing and fertilizing in the three crops is due principally to the amount of energy required to the fertilizer used.

Despite the use of herbicide, the chemical weeding remains, after rolling, the practice that requires the smallest amount of energy. This

Table 4. Diesel fuel and lubricant oil consumption.

\begin{tabular}{|c|c|c|c|c|c|c|c|c|}
\hline $\begin{array}{l}\text { Cultural } \\
\text { practices }\end{array}$ & $\begin{array}{l}\text { Diesel fuel } \\
\text { [kg/ha] }\end{array}$ & L. usitatissimum & $\begin{array}{l}\text { Incidence } \\
\text { C. sativa }\end{array}$ & B. carinata & $\begin{array}{l}\text { Oil lubricant } \\
\text { [kg/ha] }\end{array}$ & L. usitatissimum & $\begin{array}{l}\text { Incidence } \\
\text { C. sativa }\end{array}$ & B. carinata \\
\hline Shredding & 17.10 & $26.6 \%$ & $23.8 \%$ & $23.6 \%$ & 0.55 & $25.0 \%$ & $22.7 \%$ & $22.5 \%$ \\
\hline Harrowing & 12.53 & $19.5 \%$ & $17.5 \%$ & $17.3 \%$ & 0.45 & $20.6 \%$ & $18.6 \%$ & $18.4 \%$ \\
\hline Hoeing & 17.21 & $26.8 \%$ & $24.0 \%$ & $23.8 \%$ & 0.62 & $28.2 \%$ & $25.6 \%$ & $25.3 \%$ \\
\hline $\begin{array}{l}\text { Sowing and fertilizing } \\
\text { - L. usitatissimum } \\
\text { - C. sativa } \\
\text { - B. carinata }\end{array}$ & $\begin{array}{c}2.12 \\
9.54 \\
10.20\end{array}$ & $3.3 \%$ & $13.3 \%$ & $14.1 \%$ & $\begin{array}{l}0.08 \\
0.31 \\
0.33\end{array}$ & $3.5 \%$ & $12.6 \%$ & $13.4 \%$ \\
\hline Rolling & 1.10 & $1.7 \%$ & $1.5 \%$ & $1.5 \%$ & 0.04 & $1.8 \%$ & $1.6 \%$ & $1.6 \%$ \\
\hline Chemical weeding & 1.27 & $2.0 \%$ & $1.8 \%$ & $1.7 \%$ & 0.04 & $1.9 \%$ & $1.7 \%$ & $1.7 \%$ \\
\hline Harvesting & 12.99 & $20.2 \%$ & $18.1 \%$ & $17.9 \%$ & 0.42 & $19.0 \%$ & $17.2 \%$ & $17.1 \%$ \\
\hline $\begin{array}{c}\text { TOTAL L. usitatissimum } \\
\text { C. sativa } \\
\text { B. carinata }\end{array}$ & $\begin{array}{l}64.32 \\
71.75 \\
72.41\end{array}$ & $100 \%$ & $100 \%$ & $100 \%$ & $\begin{array}{l}2.19 \\
2.43 \\
2.45\end{array}$ & $100 \%$ & $100 \%$ & $100 \%$ \\
\hline
\end{tabular}

Table 5. Energy consumption for all the products used during the cultivation

\begin{tabular}{|c|c|c|c|c|c|c|}
\hline Product & $\begin{array}{l}\text { Quantity } \\
\text { kg/ha }\end{array}$ & $\begin{array}{c}\text { Energetic index } \\
\mathrm{MJ} / \mathrm{kg}\end{array}$ & $\begin{array}{c}\text { Energy required } \\
\text { MJ/ha }\end{array}$ & $\begin{array}{c}\text { L. usitatissimum } \\
\%\end{array}$ & $\begin{array}{c}\text { C. sativa } \\
\%\end{array}$ & $\begin{array}{c}\text { B. carinata } \\
\%\end{array}$ \\
\hline $\begin{array}{l}\text { Diesel fuel } \\
\text { - L. usitatissimum } \\
\text { - C. sativa } \\
\text { - B. carinata }\end{array}$ & $\begin{array}{l}64,3 \\
71,8 \\
72,4\end{array}$ & $\begin{array}{l}52,34^{[1]} \\
52,34^{[1]} \\
52,34^{[1]}\end{array}$ & $\begin{array}{l}3,366 \\
3,756 \\
3,789\end{array}$ & $28.35 \%$ & $32.99 \%$ & $33.10 \%$ \\
\hline $\begin{array}{l}\text { Oil lubricant } \\
\text { - L. usitatissimum } \\
\text { - C. sativa } \\
\text { - B. carinata }\end{array}$ & $\begin{array}{l}2,20 \\
2,43 \\
2,45\end{array}$ & $\begin{array}{l}45,51^{[1]} \\
45,51^{[1]} \\
45,51^{[1]}\end{array}$ & $\begin{array}{l}100 \\
111 \\
111 \\
\end{array}$ & $0.84 \%$ & $0.97 \%$ & $0.97 \%$ \\
\hline $\begin{array}{l}\text { Fertilizer } \\
\text { Herbicide }\end{array}$ & $\begin{array}{l}320 \\
1.0\end{array}$ & $\begin{array}{l}22.09^{[1]} \\
343.32^{[1]}\end{array}$ & $\begin{array}{c}7,069 \\
343\end{array}$ & $\begin{array}{c}59.53 \% \\
2.89 \%\end{array}$ & $\begin{array}{c}62.09 \% \\
3.02 \%\end{array}$ & $\begin{array}{c}61.75 \% \\
3.00 \%\end{array}$ \\
\hline $\begin{array}{l}\text { Seeds } \\
\text { - L. usitatissimum } \\
\text { - C. sativa } \\
\text { - B. carinata }\end{array}$ & $\begin{array}{l}39 \\
4.2 \\
5.3\end{array}$ & $\begin{array}{l}25.54^{[2]} \\
25.54^{[2]} \\
25.54^{[2]}\end{array}$ & $\begin{array}{l}996 \\
107 \\
135\end{array}$ & $8.39 \%$ & $0.94 \%$ & $1.18 \%$ \\
\hline & TOTAL & $\begin{array}{l}\text { L. usitatissimum } \\
\text { C. sativa } \\
\text { B. carinata }\end{array}$ & $\begin{array}{l}11,875 \\
11,386 \\
11,448\end{array}$ & $100 \%$ & $100 \%$ & $100 \%$ \\
\hline
\end{tabular}

[1] Baldini et al., 1982; [2] Volpi, 1992. 
is due to the small dose required for after sowing treatment for oilseed crops.

Finally, in order to calculate the total energetic Input for the cultivation of one hectare of the three different oilseed crops, the amount of biodiesel producible from each crop is estimated. By considering the yields reported in Table 2 and an oil yield of $35 \%$ for $L$. usitatissimum (Rivoira, 2001), of 38\% for C. sativa (Gugel and Falk, 2006) and of 36\% for $B$. carinata, it is possible to obtain respectively 507, 418 and 306 kilograms of vegetable oil. Moreover, a recent research shows that yields between 88 and $96 \mathrm{~kg}$ of biodiesel from transesterification of 100 $\mathrm{kg}$ of vegetable oil under alkaline catalysis condition are obtainable (Kumar et al., 2013). The authors also report that the yield differences observed are related to the amount of reagent, catalyst and process temperature employed. Taking into account a mean yield of $92 \%$ from the quantities reported above is possible to obtain the biodiesel amounts showed in Table 6 .

The total energetic Input data of the process are closely related to the yields and therefore higher values are those of $L$. usitatissimum, follow to the $C$. sativa and B. carinata. Similarly also the total amount of energy consumed follows the same order. However, the values obtained are lower than those reported in literature for other crops (Cosentino et al., 2008).

In L. usitatissimum and $C$. sativa cases, the EROEI index is bigger than one. It means that these two cultivation are energetically convenient. At the opposite the EROEI index of $B$. carinata is less than one. In this case we spent more energy than we gained from the seeds harvested. However, if we consider the average yield of 1.5 tha found by other authors, a biodiesel production of about $596 \mathrm{~kg} / \mathrm{ha}$ could be obtainable. In this way the biodiesel production could be around to $621 \mathrm{~L} / \mathrm{ha}$ which determines an EROEI index of 1.7.

\section{Conclusions}

The study aimed to verify the technical and economic feasibility of oil bearing crops such as Linum usitatissimum, Camelina sativa and
Brassica carinata, grown for energy purposes for the production of fuel oils and biodiesel. Besides these crops could also get in rotation with durum wheat also in order to improve its productivity.

The experiment performed in Sicily suggests that is possible to use non-irrigated soils for these energetic crops, but the correct cultural practices and sowing period are crucial to obtain good yields. However these were comparable with those reported in literature.

It's important to note, however, that the values of Input are lower than those reported in literature for other crops.

Moreover, in order to decrease the energy input could be reduced the amount of fertilizer to be used. In fact, it represent more than $50 \%$ of the totally energy invested.

A correct soil management could be useful to reduce weeds existent and so to eliminate the shredding that is one of the most expensive cultural practices in term of energy consumption.

In order to reduce energetic costs and work time, due to two-three tillage and rolling, the direct sowing with simultaneous tillage and sowing could be checked.

Also a correct use and choosing of the seeder can affect the energy consumptions as in the case object of study. In this regard, the cultivation of $L$. usitatissimum involves a saving of about 7-8 kg/ha compared to the other two crops considered: on larger farms, these differences can have a considerable economic impact.

The EROI index, even with the limitations inherent in the experimental test in object, is bigger than one for Linum usitatissimum and Camelina sativa, while it is less than one for $B$. carinata because of the delayed of sowing of the crop.

Although the results obtained, using the index EROEI, are partial with respect to an overall assessment which provides also for the calculation of greenhouse gas (GHG) emissions, the study in question is a first step to promote the cultivation of oil bearing crops in agricultural areas marginal or abandoned.

Moreover, it was estimated that biodiesel may be more convenient than diesel when the oil prices reach $75 € /$ barrel and even greater economic competitiveness may result from the recognition of the environmental benefits coming from the full chain of biofuels (Monti and Venturi, 2007).

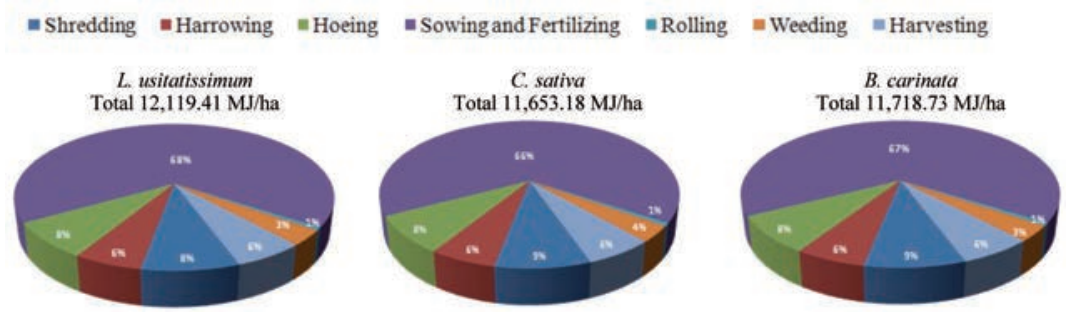

Figure 1. Energy use of machinery, diesel fuel, oil lubricant, seeds, herbicide and fertilizer for each cultural practice in the three crops.

Table 6. Input, output and EROEI index.

\begin{tabular}{|c|c|c|c|c|c|c|c|c|}
\hline \multirow[t]{2}{*}{ Crop } & Biodiesel & $\begin{array}{l}\text { Input } \\
\text { energetic } \\
\text { index }\end{array}$ & $\begin{array}{l}\text { Process } \\
\text { input }\end{array}$ & $\begin{array}{l}\text { Cultivation } \\
\text { input }\end{array}$ & $\begin{array}{l}\text { Total } \\
\text { input }\end{array}$ & $\begin{array}{l}\text { Output } \\
\text { energetic } \\
\text { index }\end{array}$ & $\begin{array}{l}\text { Total } \\
\text { output }\end{array}$ & EROEI \\
\hline & L/ha & MJ/L & MJ/ha & MJ/ha & MJ/ha & MJ/L & MJ/ha & \\
\hline L. usitatissimum & 583,62 & $5.31^{[1]}$ & 3099,05 & $12,118.34$ & 15217,39 & $37.25^{[2]}$ & 21740,03 & 1,43 \\
\hline C. sativa & 480,70 & $5.31^{[1]}$ & 2552,52 & $11,651.06$ & 14203,58 & $37.25^{[2]}$ & 17906,08 & 1,26 \\
\hline B. carinata & 351,90 & $5.31^{[1]}$ & 1868,59 & $11,719.19$ & 13587,78 & $37.25^{[2]}$ & 13108,28 & 0,96 \\
\hline
\end{tabular}

${ }^{[1]}$ Fore et al., 2011; ${ }^{[2]}$ Avella et al., 2009. 


\section{References}

Avella F., Faedo D., Macor A. Impiego di una miscela gasolio/biodiesel al $30 \%$ (B30) nei motori diesel: effetto sulle emissioni inquinanti. La rivista dei combustibili e dell'industria chimica; 2009 vol. 63 n.2, 215.

Baldini E., Alberghina 0., Bargioni G., Cobianchi D., Iannini B., Tribulato E., Zocca A. Analisi energetiche di alcune colture arboree da frutto. Numero Speciale Rivista di Ingegneria Agraria; 1982 n.2 (giugno).

Bodria L., Pellizzi G., Piccarolo P. Meccanica Agraria Vol I. Edagricole, Bologna, 2006.

Crescini F. Piante Erbacee Coltivate. I Grandi Settori dell'Agricoltura 4. Ramo Editoriale degli Agricoltori, 1969; 221-234.

Cosentino L. S., Copani V., Patanè C., Mantineo M., D’Agosta G. M. Le colture da biomassa per energia per gli ambienti italiani. Attualità e prospettive. Produzione di energia da fonti biologiche rinnovabili. 2 - Le risorse primarie. I Georgofili. Firenze 2008; 163-183.

D’Avino L., Lazzeri L., Dainelli R., Spugnoli P. Un software per la valutazione di sostenibilità delle filiere agro-energetiche. Atti del Convegno "Attualità della ricerca nel settore delle energie rinnovabili da biomassa". Ancona, Facoltà di Agraria, 16-17 dicembre. 2010; 391-400.

Fore S. R., Porter P., Lazarus W. Net Energy balance of small-scale on farm biodiesel production from canola and soybean. Biomass and Bioenergy 35, Elsevier, 2011; 2234-2244.

Francis A., Warwick S.I. The Biology of Canadian Weeds. 142. Camelina alyssum (Mill.) Thell.; C. microcarpa Andrz. ex DC.; C. sativa (L.) Crantz. Canadian Journal of Plant Science 89(4), 2009; 791-810.

GSE 2012. Rapporto Statistico 2011, Impianti a Fonti Rinnovabili.

Gugel R.K., Falk K.C. Agronomic and seed quality evaluation of Camelina sativa in western Canada. Canadian Journal of Plant Science 2006; 1047-1058.

Lazzeri L., D’Avino L., Mazzoncini M., Antichi D., Mosca G., Zanetti F., Del Gatto A., Pieri S., De Mastro G., Grassano N., Cosentino S., Copani V., Ledda L., Farci R., Bezzi G., Lazzari A., Dainelli R., Spugnoli P. On farm agronomic and first environmental evaluation of oil crops for sustainable bioenergy chains.Italian Journal of Agronomy, 2009, Vol. 4 (4), p. 171-180.

Mazzoncini M., Vannozzi G.P., Megale P., Secchiari P., Pistoia A., Lazzeri L. Ethiopian Mustard (Brassica Carinata A.Braun) Crop in Central Italy. Note 1: Characterization and agronomic evaluation. Agricoltura mediterranea 1993; 123, 330-338.

Monni M. La strategia nazionale per lo sviluppo energetico. Mondo Macchina, anno XXII, 2013; n. 3-4. 44-45.

Monti A., Venturi G. Il contributo delle colture da energia alla sostenibilità ambientale. Accademia Nazionale di Agricoltura. Annali Edizione straordinaria CXXVII (Anno 2007). Bologna.

Murphy D. J., Hall C. A. S. Year in review EROI on energy return on (energy) invested. Annals of the New York Academy of Sciences 2010; 1185, 102-118, New York.

Ortenzi M. Europa ed agro energie, un quadro articolato. Mondo Macchina, anno XXII, 2013; n. 3-4; 42-43.

Pracha A. S., Volk T.A. An Edible Energy Return on Investment (EEROI) Analysis of Wheat and Rice in Pakistan. Sustainability 3, Elsevier $2011 ; 2358-2391$.

Progetto Fi.Sic.A. (Filiera Siciliana per l'Agroenergia). Studio di fattibilità per l'introduzione di filiere agro-energetiche in Sicilia. A cura di B. Messina, V. D’Anna, R. Paci, F. Viola. 2008.

Riva G., Foppa Pedretti E., Toscano G. Biocombustili e biocarburanti: aspetti generali e tecnici della loro produzione e utilizzo. Produzione di energia da fonti biologiche rinnovabili. 1 - Le tecnologie. I Georgofili. Firenze 2008; 163-183.

Rivoira G. Lino (Linum usitatissimum L.) - Coltivazioni Erbacee, piante oleifere, da zucchero, da fibra, orticole e aromatiche. vol. 2, 213218, Pàtron Editore 2001.

Unakitan G., Hurma H., Yilmaz F. An analysis of energy use efficiency of canola production in Turkey. Energy 2010; n.35; 3623-2627.

Verani S., Sperandio G., Picchio R., Savelli S. Nozioni di base per la costituzione di micro filiere energetiche di autoconsumo. Progetto sportello COFEA. Tipografia Bonanni, Roma 2008.

Volpi R. Bilanci energetici in agricoltura. Laruffa Editore, Reggio Calabria 1992.

Zubr J. Oil-seed crop: Camelina sativa. Industrial Crops and Products 6, Elsevier 1996; 113-119. 